\title{
Legacy of the Secret War: Medical Needs in the UXO-Contaminated Areas in Laos.
}

\author{
Masabiro Morikawa, MD, MPH
}

Laos is a small country about the size of Utah. A Lao physician jokingly told me with a sad smile that "Americans thought Laos was a part of Vietnam during the war." The war in Laos was, however, an intentional secret war. The number of bombs dropped during the Vietnam War was greater than the bombs dropped in Europe during World War II. This bombing, which left an enormous number of UXOs (unexploded ordnances), has created a silent public health emergency in Laos today.

In any war, including the Gulf War, as much as 20 percent of the munitions remain unexploded in the ground, endangering anyone engaged in daily activities in the rice fields or a school yard. Nearly one half of the victims of UXO injuries in Laos are children younger than 15 years. In many postconflict countries agricultural production is estimated to increase 150 percent if there are no land mines, a type of UXO. There is no doubt that the longterm impact caused by UXOs is serious physically, socially, and psychologically.

According to the 1997 National UXO Survey by Handicap International, a French nongovernmental organization, the highest priority for UXO clearance is given to the districts along the Ho Chi Minh Trail in the southern province, and the second highest priority is given to the districts in Xieng Khouang province in the northwest. The prioritization of the Handicap International survey was based not only on the number of UXOs remaining but also on the proximity of UXOs to populated areas. I will describe the medical needs in Xieng Khouang and the districts around the Ho Chi Minh Trail, where I visited during 1997.

Submitted 8 May 1998.

From the Department of Family Medicine, Case Western Reserve University, Cleveland. Address reprint requests to Masahiro Morikawa, MD, MPH, Department of Family Medicine, Case Western Reserve University, 11000 Euclid Ave, Cleveland, OH 44106.

\section{Surgical Training Course in Xieng Khouang}

Xieng Khouang was among the targets of secret bombing by the United States between 1963 and 1972. The Plain of Jars, where more than 200 stone jars are mysteriously scattered around, was bombed almost every 8 minutes during these 9 years. The bomb craters are everywhere in the mountains and rice fields, and so are rusted mortar shells.

In the provincial hospital of Xieng Khouang, there are always 5 to 6 patients with UXO injuries. Because the most common UXO found in Laos is a fragmentation mine called BLU 24 or 26 , the UXO-related injuries are shrapnel wounds caused by the bomb fragments. The actual number of the injuries and the deaths caused by UXOs is unknown, however, as many patients with serious injuries and those injured in remote villages might not have reached the hospital.

Improvements in the educational system have been delayed in Laos. As a result of a lengthy period of colonization and the devastating effects of the war, per capita income is $\$ 200$ per year, putting Laos among the most impoverished countries. Opportunities for postgraduate medical training are extremely limited. To help the Xieng Khouang health professionals acquire confidence in treating patients with UXO as well as other injuries, an American surgeon, the daughter of a Christian missionary who grew up in Laos, and I planned and implemented a surgical training program, "Surgical Care of the Wounded," in February 1997.

Our 7-day training program, designed to provide basic surgical knowledge and skills, consisted of lectures, bedside teaching, and case discussions, with a focus on basic life support. We also compiled a field manual in both English and Lao, which for these participants was their first textbook of surgery. We received positive feedback during and after the course and have been asked to plan similar courses in the near future. 


\section{UXO Problems Around the Ilo Chi Minh Trail}

After the success of our training program in Xieng Khouang, I visited four district hospitals in Xepone, Vilabury, Nong, and Phine along the Ho Chi Minh Trail in southern Laos in December 1997. As a consultant for the Lao Ministry of Health, I assessed the health care needs in the districts as well as the Lao physicians' needs for a training program similar the one we provided in Xieng Khouang. In fact, Handicap International categorized three districts, Xepone, Vilabury, and Nong, as the highest priority areas for UXO clearance in the National UXO Survey.

Lack of clean running water and a chronic shortage of medical supplies are not unusual in Laos except in the capital city of Vientiane. Compared with Xieng Khouang, where electricity is available at least between 6 and $11 \mathrm{pm}$, there is no constant supply of electricity in the districts along the Ho Chi Minh Trail. In the hospitals only 1 or 2 physicians take care of up to 20 inpatients in addition to their busy outpatient duties. As requested, I examined surgical equipment in each of the district hospitals. Most scissors were dull and obstetric forceps did not fit properly. Nonetheless, the demands for surgeries, particularly appendectomy, cesarean section, and tubal ligation, are very high.

The physicians perform emergency surgeries, deliver babies, and care for UXO victims as well as treat malaria or diarrhea in pediatric patients. They are the first and the only health care provider for all kinds of health problems, and referral to the provincial hospital is practically impossible. There is no distinction between surgeons and physicians, and specialist consultation is not available. In other words, the physicians have developed skills to utilize best their limited resources, which would make most Western physicians accustomed to modern medical facilities uncomfortable when dealing with these problems.

Physicians at district hospitals expressed serious concerns about their lack of postgraduate training. Indeed, I observed that they spent little time examining patients on daily rounds, which primarily focused on discussions of symptoms with patients and their families and a brief check of vital signs taken the previous day. Judgments concerning diagnoses and progress were based mainly on the history of the illness. Lack of skills in physical diag- nosis caused these physicians to rely more on other diagnostic modalities, most of which are not available at the district hospitals. They often asked for high-tech equipment, such as a blood chemistry analyzer or text kits to detect human immunodeficiency virus infection, as a panacea for diagnosis. They had little understanding about false-positive or false-negative test results.

What Skills Would Help Them? Primary Care Training A closer look at the available community-based data shows an unusually high rate of injuries among children younger than 15 years compared with children in other countries, such as Cambodia or Mozambique. This finding is probably related to the type of ordnance found in Laos. Yet there are fewer UXO incidents in Laos than there are land mine incidents in, for example, Angola or Cambodia. Given the current political stability in Laos, the international community has not paid much attention to the UXO issues. UXO issues also do not attract grant funding.

Because the medical infrastructure seems unlikely to change in the near future, the population will continue to suffer from UXO injuries. Some ordnance experts say it will take at least another 100 years to clear the UXOs from the country. Even though I started my project specifically for UXO injuries, which are life-threatening, I became aware of the need at district hospitals for comprehensive medical care equivalent to family practice in this country.

To make this training really sustainable and effective, it is important to organize courses in the context of primary care to include (1) basic surgical skills, (2) comprehensive medical skills with an emphasis on physical diagnosis, (3) public health skills to maximize health promotion and prevention, (4) community assessment skills based on clinical epidemiology, and (5) problem-solving skills in daily practice.

Our program in these districts will focus on generalist training by a multidisciplinary team of instructors. We would like to continue these efforts to help train district health officials for the next several years. I now realize that the elements we need for our training in Laos are the same elements important for training family physicians in the United States. 